УДК:811.111(072)

DOI: $\underline{10.35619 / \text { iiu.v2i13.338 }}$

Olena Kasatkina-Kubyshkina

$\mathrm{PhD}$ in Psychology, Associate Professor, Associate Professor at Practice of English Language Department

Rivne State University for the Humanities,

Rivne, Ukraine

ORCID: 0000-0002-1265-04956

e-mail:yelena123@ukr.net

Alla Fridrikh

$\mathrm{PhD}$ in Pedagogy, Associate Professor, Associate Professor at Practice of English Language Department

Rivne State University for the Humanities,

Rivne, Ukraine

ORCID: 0000-0001-9072-1845

e-mail: allafridrikh@gmail.com

Yuliia Kuriata

Ph.D in Psychology,

Associate Professor at Practice of English Language Department

Rivne State University for the Humanities,

Rivne, Ukraine

ORCID: 0000-0002-0059-7586

e-mail:viktorivnayuliia@gmail.com

\title{
PROJECT-BASED LEARNING IN A FOREIGN LANGUAGE CLASSROOM: PECULIARITIES OF IMPLEMENTATION
}

\begin{abstract}
The article deals with the aspects of project-based learning (PBL) for teaching foreign languages. The authors state that although PBL has much in common with task-based learning, which makes a task the central target of a lesson, PBL often makes it a whole semester or even academic year target and promotes learner centeredness to a higher level. PBL is usually comprised of three main stages: pre-task stage, performance stage and presentation stage which have their own peculiarities and standards to comply.

Project-based learning allows students to achieve the highest level of mastery of a foreign language as it leads them to higher-order thinking, prepares them for academic, personal, career success, and makes young people ready to meet the challenges, gain the $21^{\text {st }}$ century skills. Struggling students and students' misbehavior and reluctance are considered to be essential factors that keep teachers away from implementing the method into life. Practical guidelines are given on how to get over obstacles and how to evaluate the outcomes of project work. The authors emphasize on the necessity of careful planning, team formation which will meet the needs of all the students, and

(C) Olena Kasatkina-Kubyshkina,
\end{abstract}

Alla Fridrikh,

Yuliia Kuriata, 2021 


\section{Інноватика у вихованні. Випуск 13.Том 2. 2021.}

elaboration of a rubric with sharply defined criteria (e.g., needs, accommodations, modifications, assets and team position) to evaluate students.

Keywords: project-based learning, task-based learning, twenty-first century skills, learner centeredness, feedback, team formation, rubric.

Problem statement. In recent years the issue of the application of new forms, methods, and approaches to teaching foreign languages in high school is becoming increasingly important. Thus, the major teacher's tasks are not to pass on information and instructions on how to use it, but to create such learning conditions for each student where they can gain practical language learning skills, to choose such methods of teaching that would encourage every student to make use of their activity, creativity, to perfect linguistic, cognitive, educational and socio-cultural competences, as well as to increase students' higher-order thinking skills in learning foreign languages. The use of cooperative learning and project-based technology, as well as modern Internetbased technology can help in pursuing these objectives.

Research publications analysis. The foundations of the basis of projectbased approaches were formed over a century ago by John Dewey who emphasized on the benefits experimental, hand-on, student-directed learning had. Since then scholars all over the world have made it the object of study and analyzed its various aspects (Bell, S., Blank, W., Blumenfeld, P., Foshay, J., Harris, J., Harwell, S., Kilpatric, W., Learner, J., Mergendooler, J., Westwood, P., etc). Project-based learning has been defined in various ways and is often referred to as a "model", "approach", "method", "technique", "learning", or "teaching". In general, PBL can be defined as "... an authentic learning model or strategy in which students plan, implement, and evaluate projects that have real-world applications beyond the classroom" (Blank, Harwell, 1997; Smith, 2007; Bettinger, Long, \& Taylor, 2016). Nonetheless, the peculiarities of incorporation of PBL in classrooms as well as effective ways to form groups and develop a rubric were not studied to the fullest extend and need some extra specification which becomes the subject-matter of the article.

Presenting the main research material. Project-based learning (PBL) which combines the elements of problem-based learning and collaborative learning is one of the most successful current methods in teaching foreign languages as it allows achieve the highest level of mastery of any subject in general, and foreign language in particular. It challenges students to think beyond the boundaries of the classroom, prepares students for academic, personal, and career success, and prepares young people to deal with the challenges and form skills needed for success in the $21^{\text {st }}$ century (Bell, 2010; Swartz, 2020).

It provides students with skills to question, analyze, evaluate information, their plans and conclusions they reach, and create new ideas in such a way that it leads them to higher-order thinking. It is an undeniable fact that PBL forms students' communication skills, promotes culture and communication, improves consecutive reasoning, helps tolerate others' opinions, enables students to 


\section{Інноватика у вихованні. Випуск 13.Том 2. 2021.}

extract information from a variety of sources and process it with the help of IT. From there, the natural need to interact in a foreign language arises.

As project work manifests the ability to work independently with reference books, find necessary information in various sources, and see links with other branches of knowledge, it also forms students' computational thinking skills , i.e. "...the ability to solve problems that include gathering and organizing data to investigate questions and communicate findings" (Day, 2017; Bonderud, 2019). In addition, through active learning students develop "team spirit" and the ability to find ways to solve problems which is essential for their further occupation.

Project-based learning does not contradict the traditional ways of learning. It helps to activate students since most of them have an interest for new knowledge.

Interest is often considered to be the main source that contributes to learning because it enhances the latter, which then leads to better performance and achievement. Interest transforms into motivation - the desire to successfully develop the theme of the project. It is often stronger than the demands of parents and teachers to study hard in order to get excellent and good marks. Consequently, extrinsic motivation transfers into intrinsic one, which boosts learning outcomes (Blumenfeld, Soloway \& Marx, 1991; Gayle \& Kaufeldt, 2015).

To make this method of teaching effective and applicable, it was based on the key principles of education science, expressed by many progressive educators: promotion of manual activity instead of memorization and verbalism, learners' active participation in the learning process, and exploitation of facts relating to the immediate reality as a source for learning (Crisafidis, 2005; Fragoulis, 2009).

The PBL approach takes learner-centeredness to a higher level and, although it shares many aspects with task-based learning, which makes a task the central focus of a lesson, PBL often makes a task the focus of a whole term or academic year.

Though different teachers approach project work in different ways and use it as the basis for a whole year's work or dedicate just a certain amount of time alongside the syllabus, or use projects only on short courses, there are still four elements generally considered to be common to all project-based activities/classes:

a central topic from which all the activities derive and which drives the project towards a final objective;

access to means of investigation to choose, collect, analyze and use information;

interaction with other learners is fundamental to $\mathrm{PBL}$, which provides plenty of opportunities for sharing ideas, collaborating and communicating;

presence of a final product in the form of portfolios, essays, posters, presentations, reports, videos, webpages, blogs, etc. 


\section{Інноватика у вихованні. Випуск 13.Том 2. 2021.}

There are three distinct stages of PBL: pre-task stage, performance and presentation stages.

To put into practice a pre-task stage, a teacher should demonstrate a model of how students can approach new ideas, information, and problems, as providing students with skills for metacognition and self-direction will help them not only in all subject areas but in real life. At this stage it is necessary to establish learning goals, and once a teacher has determined exactly what students should understand when they finish a project, framing project work becomes much easier. The tasks of a teacher at this stage is to help students to write an essential question that will drive the project, to develop an authentic task and a set of criteria for a summative assessment of the final product and product presentation.

At the second, performance stage the following key elements of a good project should be distinguished:

purpose and relevance: here we are to answer the questions if the project is personally meaningful and whether it prompts interest in the learner to have him/her invest time, effort, and creativity in the development of the project;

time that must be provided for learners to think about, plan, execute, correct flaws, change, expand, and edit their projects;

complexity: as the best projects combine interdisciplinary skills and multiple subject areas, they call upon the prior knowledge of each student;

being connected: during project work students are connected to each other, experts, multiple subject areas, powerful ideas, etc.;

access to a wide variety of concrete and digital materials anytime, anyplace is essential as well. It is recommended that teachers think about the quality and quantity of craft materials, books, tools, etc. that are to be used by learners to follow the paths;

being shareable: if students have to make something that is shareable with others, this provides a great deal of motivation, relevance, perspective making, and reciprocal learning;

novelty, i.e., if one student makes a fantastic discovery during a project, others can learn from it without slavishly repeating the steps of the pioneering student.

Culmination of project-based learning is a final presentation of learning itself. At this stage students receive nonstop feedback from teammates, their instructor, mentor, and others involved in the project. However, presentations need to be more than just an introduction to the product or learning artifact and positive emotions. To reach the goal, i.e., affirm cognitive growth and learning, a teacher needs to involve and make everyone participate: the student presenting learning, the audience, the facilitator.

Before any type of presentations, norms should be established for sharing feedback on the project content and delivery for every single participant. The audience should also share observations, reflections, and ideas brought up as students share their learning. It is beneficial to ask the audience what they learned about the subject matter content, if presentation strategies were 


\section{Інноватика у вихованні. Випуск 13.Том 2. 2021.}

effective and technology was used purposefully, how the idea/ product engaged them and if it could be revised or extended, etc. At the stage of presentation everyone should be reminded that the information might be criticized but only if it is free of value judgments, immediate enough to be useful, specific, personal, and directed at one's work, and comes from someone who is knowledgeable and respected.

Presenters should know that teachers expect their final presentation to be a presentation of their learning through the project-building process, not just a demonstration of the product they create. Therefore, the following aspects that students learned about should be included: the subject matter content; reflection on planning, organizing, and implementing a project, how they learned and how their group functioned. To promote reflection, they might be asked what they would do differently if they had the opportunity to do this project again, what they would change in their product/idea/design if they had more time, etc.

The instructor for his/her part should share insights on the product, and reflect on presentation itself and audience thoughts via open-ended questions that inspire further group discussion or a written self-assessment (how did you make a difference for your team; how did you solve problems and obstacles emerging during the project (individually, procedurally, and/or collaboratively); what is the most important thing you learned during your work on this project, etc.?).

According to Aitken, L. (2019) the study uncovered that the more challenges teachers identified, the less frequently they used PBL. Among the most frequently named challenges on the part of teachers identified were: lack of time to collaborate with colleagues; lack of access to technology; lack of resources; students lacking maturity to fully take part in PBL; lack of time to properly implement. On our part, we would state there are two main concerns related to students that might keep Ukrainian teachers from incorporating PBL in classrooms:

students are too low: It is a common practice to have struggling students in the class, however it is possible to engage them with the right questions and tasks. It is crucial to plan out the questions that will be asked and be prepared to listen to what these students have to say. Due to this, students may get an opportunity to express their different interests, which will allow a teacher to get to know them better, to adjust the task itself and make the right grouping. If the steps are taken properly, this will trigger the students to ask extra questions and dive deeper into the topic, not only relying on somebody who is higher level but to seek out information on their own knowing they are allowed the freedom to explore a topic. To promote this, teachers can add extra credits for their final result;

students' misbehavior and reluctance. However, if they are engaged, they are less likely to misbehave. It is not effective to provide students with readymade tools and guidance and expect them to be engaged. Teachers need to take time to plan each day of PBL with a new activity that will make students ask a lot of questions, dedicate each day to a specific task or topic, and let the room 


\section{Інноватика у вихованні. Випуск 13.Том 2. 2021.}

for the students to work towards it in a different way as this is what keeps them interested in the topic.

It is possible to approach team formation of students by selecting the members properly, and by placing each student carefully in a position that manifests individual's strengths to construct a winning team. This can be presented in the form of a table:

Table 1

Team Formation Rubric Sample

\begin{tabular}{|l|l|l|l|l|l|}
\hline Student & \multicolumn{1}{|c|}{ Needs } & $\begin{array}{l}\text { Accomodatio } \\
\text { ns }\end{array}$ & $\begin{array}{l}\text { Modifi } \\
\text { cations }\end{array}$ & \multicolumn{1}{|c|}{ Assets } & \multicolumn{1}{c|}{$\begin{array}{c}\text { Team } \\
\text { position }\end{array}$} \\
\hline Student 1 & $\begin{array}{l}\text { Shy/ } \\
\text { quiet }\end{array}$ & $\begin{array}{l}\text { Colaboration } \\
\text { with Student 3 }\end{array}$ & - & $\begin{array}{l}\text { Reading and } \\
\text { writing }\end{array}$ & $\begin{array}{l}\text { Research } \\
\text { organizer }\end{array}$ \\
\hline Student 2 & $\begin{array}{l}\text { Low } \\
\text { musical } \\
\text { intelligen } \\
\text { ce/high } \\
\text { visual- } \\
\text { spatial } \\
\text { Intelligen } \\
\text { ce }\end{array}$ & $\begin{array}{l}\text { Printed } \\
\text { directions }\end{array}$ & - & $\begin{array}{l}\text { Good at art, } \\
\text { visual } \\
\text { perception }\end{array}$ & $\begin{array}{l}\text { Art } \\
\text { manager }\end{array}$ \\
\hline Student 3 & $\begin{array}{l}\text { Average } \\
\text { student/ } \\
\text { high } \\
\text { interpers } \\
\text { onal } \\
\text { intelligen } \\
\text { ce }\end{array}$ & - & - & $\begin{array}{l}\text { Active, } \\
\text { outspoken }\end{array}$ & Presenter \\
\hline Student... & $\begin{array}{l}\text { Average } \\
\text { student, } \\
\text { needs to } \\
\text { be } \\
\text { pushed }\end{array}$ & $\begin{array}{l}\text { Printed } \\
\text { directions, list } \\
\text { of questions/ } \\
\text { tasks to solve }\end{array}$ & - & $\begin{array}{l}\text { Writing, } \\
\text { organizing }\end{array}$ & $\begin{array}{l}\text { Team } \\
\text { editor }\end{array}$ \\
\hline
\end{tabular}

This sort of planning helps to meet the needs of the students, and it helps each student to realize that everyone has strengths and weaknesses.

To help all students succeed in project work, a teacher needs to develop a rubric with sharply defined criteria to evaluate students. Although there are no unified, ideal criteria to follow, as much depends on particular characteristics of a class, some aspects should be considered:

Attitude. As student performance often rises or falls according to teacher's expectations, it is beneficial to have a positive attitude and encourage all the students to work hard to be successful.

Knowing the students. If teachers really aware of student strengths and weaknesses, they can build teams whose strengths complement each other. 


\section{Інноватика у вихованні. Випуск 13.Том 2. 2021.}

Knowing the project. The standards that a project addresses and the procedures that need to be followed should be known by all teams. The clearer the objectives and procedures are, the more successful students can become.

Providing options. Every classroom is full of diverse students who may learn best through reading, talking, dancing, or doing hands-on construction. Successful projects take this diversity of learners into account and provide many ways to express understanding. Special needs students succeed when they have access to options that help them build on their strengths rather than concentrate on their deficits.

Conclusion and further research prospects. Consequently, it is generally assumed that the teacher's role in PBL is not dominant, but he/she acts as a guide, advisor, monitor, coordinator, designer and facilitator who sets up frameworks for communication, provides access to information and helps with language where necessary, gives students opportunities to produce a final product or presentation. As with TBL, the teacher, in general, monitors interaction but does not interrupt, deals with language/ grammar problems at another moment. It means that when implementing the project-based method the crucial point of the learning process shifts from the teacher to the learners, from working alone to working in groups.

\section{REFERENCES}

Westwood, P. (2008). What teachers need to know about teaching methods. Camberwell, Victoria: Acer Press.

Blank, W., Harwell, S. (1997). Authentic instruction. Promising practices for connecting high school to the real world. Tampa, FL: University of South Florida.

Smith, G. (2007). The Importance of Effective Instruction in Determining Student Success: Background for Defining the Role of Faculty Development at UNM, Vol. 6: University of New Mexico. URL: https://core.ac.uk/download/pdf/151611085.pdf. [Aaccessed 22.01.21].

Bettinger, E., Long, B. \& Taylor, E. (2016). When Inputs are Outputs: The Case of Graduate Student Instruction. Economics of Education Review, Vol. 52. PP. 63-76.

Bell, S. (2010). Project-based learning for the 21st century: Skills for the future. The Clearing House: A Journal of Educational Strategies. Issues and Ideas. Vol. 83 (2).

Swartz, S. (2020). Using Project-Based Learning to Develop $21^{\text {st }}$ Century Skills. Discovery Education, URL: https://www.csrwire.com/press_releases/44688-using-project-based-learning-todevelop-21st-century-skills. [Accessed 22.01.21].

Day, E. (2017). How Can We Bring Coding into Authentic PBL? URL: https://www.gettingsmart.com/2017/12/how-can-we-bring-coding-intoauthentic-pbl/. [Accessed 22.01.21].

Bonderud, D. (2019). How Project-Based learning is Helping Students Build $21^{\text {st }}$ Century Skills: A new pedagogy that focuses on a mixture of 


\section{Інноватика у вихованні. Випуск 13.Том 2. 2021.}

education technology, soft-skill building and real-world examples is sweeping through $K-12$ classrooms

URL: https://edtechmagazine.com/k12/article/2019/11/how-project-based-learninghelping-students-build-21st-century-skills-perfcon. [Accessed 22.01.21].

Blumenfeld, P., Soloway, E., Marx, R., Krajcik, J., Guzdial, M. \& Palincsar, A. (1991). Motivating project-based learning: Sustaining the doing, supporting the learning. Educational Psychologist, Vol. 26 (3-4). PP. 369-398.

Gayle, G., Kaufeldt, M. (2015). The Motivated Brain: Improving Student Attention, Engagement, and Perseverance. Alexandria, VA: ASCD. URL: http://www.ascd.org/Publications/Books/Overview/The-Motivated-Brain.aspx.

[Accessed 22.01.21].

Crisafidis, K. (2005). Experiential-communicative teaching. Implementing the project method in school. Athens: Gutenberg, URL: https://www.files.eric.ed.gov > fulltex. [Accessed 22.01.21].

Fragoulis, I. (2009). Project-Based Learning in the Teaching of English as a Foreign Language in Greec Primary Schools: From Theory to Practice. English Language Teaching. Vol. 2 (3). PP. 113-119.

Aitken, L. (2019). Teacher perspectives on using project-based learning, URL: https://www.teachermagazine.com.au , articles , tea. [Accessed 22.01.21].

\section{ПРОЄКТНА МЕТОДИКА У НАВЧАННІ ІНОЗЕМНОЇ МОВИ: ОСОБЛИВОСТІ ВПРОВАДЖЕННЯ}

\begin{abstract}
Касаткіна-Кубишкіна Олена
кандидат психологічних наук, доцент, доцент кафедри практики англійської мови Рівненського державного гуманітарного університету, м. Рівне, Україна ORCID: 0000-0002-1265-0495 e-mail:yelena123@ukr.net Фрідріх Алла кандидат педагогічних наук, доцент, доцент кафедри практики англійської мови Рівненського державного гуманітарного університету, м. Рівне, Україна ORCID: 0000-0001-9072-1845 e-mail: allafridrikh@gmail.com
\end{abstract}

Курята Юлія

кандидат психологічних наук, доцент, доцент кафедри практики англійської мови Рівненського державного гуманітарного університету,

м. Рівне, Україна

ORCID: 0000-0002-0059-7586 e-mail: viktorivnayuliia@gmail.com 
Анотація. У статті розглядаються основні аспекти впровадження проєктного навчання у викладанні іноземних мов. Проєктне навчання - це інноваційний підхід до навчання в умовах шкіл України, який навчає безлічі стратегій, важливих для успіху у XXI столітті. Автори констатують, що проєктне навчання сприяє студентоцентризму та просуває його на більш високий рівень. Автори досліджують три основні етапи проєктно-орієнтованого навчання та аналізують особливості їх реалізації на заняттях іноземної мови. Узагальнено, що дане навчання повинно містити чотири основні компоненти: основна (провідна тема); доступ до засобів збору, аналізу, обробки та використання інформації; взаємодія з усіма студентами; наявність кінцевого продукту у вигляді портфоліо, есе, відео, блогів, звітів, графіків тощо. Зазначається, що навчання на основі проєктів дозволяє студентам досягти найвищого рівня володіння іноземною мовою, оскільки воно формує мислення вищого порядку, сприяє формуванню ключових навичок XXI століття. Даний підхід сприяє трансформації зовнішньої мотивації у внутрішню, а також допомагає студентам перейти від навичок мислення нижчого порядку до мислення вищого порядку з метою формування креативності, уяви, критичного мислення, навичок співпраці, лідерства, цифрової компетентності та майбутньої активної громадянської позиції. Автори роблять припущення, що основними причинами, які стримують педагогів від широкого запровадження даного підходу можуть бути неготовність та небажання студентів до самостійного критичного опрацювання та осмислення інформації, низький рівень уміння здійснювати зворотній зв'язок. У статті наводяться рекомендації щодо подолання основних перешкод у впровадженні методу проєктів, а також оцінювання результатів роботи над проєктами. Автори наводять практичні рекомендації щодо планування навчального процесу, формування груп та розробки чітких критеріїв організації та оцінювання із урахуванням потреб студентів, умов їх залучення до групової роботи, необхідності внесення поправок тощо з метою кінцевого оцінювання студентів.

Ключові слова: проєктно-орієнтоване навчання; навчання, спрямоване на вирішення завдань; мислення вищого порядку; навички XXI століття; зворотній зв'язок, групоутворення; критерії оцінювання.

Стаття надійшла до редакиії 26.01.2021p. 